\section{Japan and}

JAPAN's hunger for tropical timber, of which it is the world's largest consumer, has drawn its attention to the Amazon rain forests and onto a collision course with international organizations concerned about the shrinkage of the tropical forests.

Japanese imports of tropical timber from Brazil began last November and Japan's greatly increased overseas aid (just under $\$ 10,000$ million this year) may soon help to finance a road linking the upper reaches of the Amazon Basin with the Pacific coast of Peru, opening up vast tracts of the forest to exploitation. But environmentalists and US legislators concerned about the possible adverse

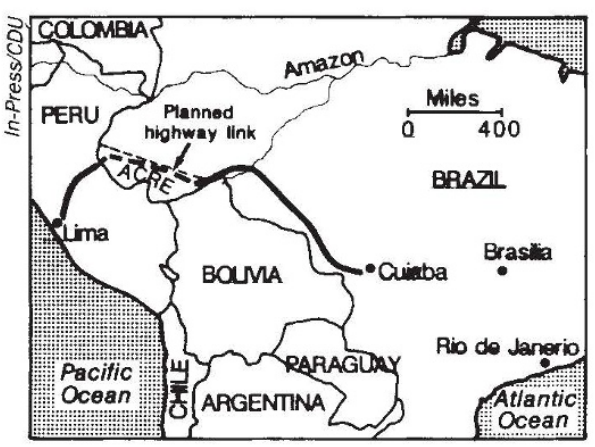

A new link to Pacific ports could cut time needed to ship out timber from the Amazon.

effects of deforestation on the world's climate plan to fight the proposal.

The new road, backed by Flaviano Melo, governor of the Amazonian state of Acre, would link up with the transAmazon highway which connects ports on Brazil's Atlantic coast with Acre. But that highway, built with funds from the World Bank and the Inter-American Development Bank (IADB), brought destruction to Brazil's rainforests as more than a million migrant peasants moved up the road, burning and clearing adjacent forest for temporary subsistence farms. Subsequent IADB loan disbursements for road improvements in Acre were blocked after opposition in the US Senate. So Melo has turned to Japan for money.

Senator Robert Kasten (Republican, Wisconsin), who was instrumental in bringing World Bank and IADB support to a halt, announced at a Senate Commerce Committee hearing on global climate change last week that he has introduced legislation calling on the US Secretary of State to oppose Japan's "reported" plans to finance the new road with overseas aid. The matter was taken a step further when US President George Bush, in Tokyo for the funeral of the late Emperor Showa, reminded Japan's Prime Minister Noboru Takeshita of concern over global environmental problems and deforestation, although he did not speci- fically mention the Acre road.

Japanese Foreign Ministry officials say no agreement to finance the road has been made. But Japan is ready to make huge loans to Brazil and, according to the Washington-based Environmental Defense Fund, the terms of earlier loans to Brazil have often been breached.

Kasten's legislation is sure to draw attention to Japan's recent moves into the Amazon. After a quiet beginning last November, Japanese imports from Brazil soon caused great embarrassment for the two countries when disclosed a few weeks later at a meeting of the International Tropical Timber Organization (ITTO) in Yokohama. In September, Brazil's president Jose Sarney announced an export ban on raw logs so as to develop an indigenous timber-processing industry and to slow the destruction of Amazonian forests. But Japan circumvented the ban (with Brazil's approval) by taking timber from areas cleared for a hydroelectric project financed with overseas aid.

Japan now gets most of its timber imports from South-East Asia. But supplies are beginning to dry up. Indonesia and the Philippines have banned exports of raw logs and have begun processing their own timber. In response, Japanese trading companies switched attention to Malaysia. But Malaysia's tropical forests are rapidly being depleted, and Japan is now turning to Brazil, and to the Amazon.

Now the world's largest overseas aid donor, Japan plans to channel thousands of millions of dollars into South America, in particular Brazil. World Bank and IADB loans to developing countries are already under severe scrutiny because many giant projects have had unforeseen environmental side-effects. Japan can expect the same tough criticism of its loan plans. David Swinbanks \& Alun Anderson

\title{
Wild chimpanzees endangered
}

\section{Washington}

WILD chimpanzees, previously classified as 'threatened', have now been reclassified as an 'endangered' species by the US Fish and Wildlife Service. As a result, it will now ordinarily be illegal to import into the United States chimpanzees or their young which have been caught in the wild. But captive chimpanzees now in US zoos and biomedical research facilities will remain in the 'threatened' category, which entails fewer restrictions on movement.

Because of their likeness to human beings, chimpanzees have been valuable animals for biomedical research, raising serious concern about the survival of wild chimpanzee populations.

The new rules were prompted by a petition filed more than a year ago by the Humane Society of the United States, the World Wildlife Fund and the Jane Goodall Institute. Flooded by comments supporting the proposal, the Fish and Wildlife Service announced its intention to reclassify the chimpanzee late last year (see Nature 336, 511; 8 December 1988).

One significant subtlety in the rules now published is that, while captive chimpanzees in the United States will remain classified as 'threatened'. captive chimpanzees in Africa will be redesignated as 'endangered". Conservationists hope this will prevent poachers from selling newly captured animals.

The new classification is not universally acclaimed. The US National Institutes of Health (NIH) have opposed it, arguing that there should be a systematic survey of wild chimpanzees before the import restrictions are tightened. But conservationists have denounced this pro- posal as a delaying tactic to keep open the door by which wild chimpanzees could reach research laboratories.

With stricter rules now in place, Curtis Bolin says that the World Wildlife Fund will test NIH's sincerity by offering to join it in a new study of wild chimpanzees in Africa. Deputy director William Raub says that NIH may be interested in surveying several other primate species as well.

Under the new rules, all major facilities in the United States housing captive chimpanzees will have to account each

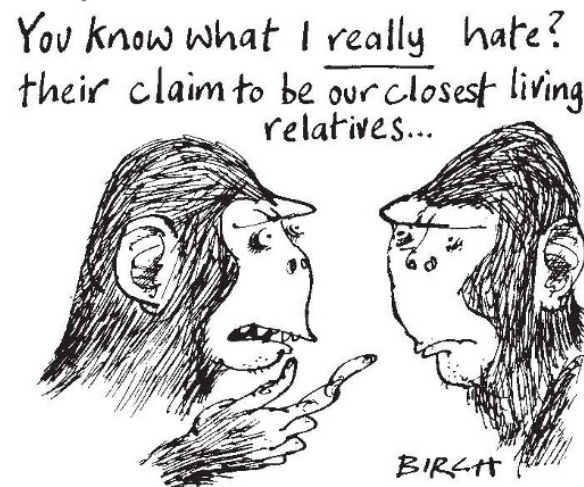

year for the numbers of their chimpanzees as well as their health and breeding status.

Conservationists' suspicions that biomedical researchers have been subverting efforts to protect the chimpanzee have been rife since Robert Gallo told an international conference several years ago that he would favour importing wild chimpanzees for use in AIDS research. Gallo is now seeking to mend fences: a statement by him that AIDS research no longer needs chimpanzees from the wild is expected to appear soon in the popular magazine The New Yorker. Carol Ezzell 